\title{
Smear Layer in Endodontics: A review of its role and management
}

\author{
Asma Abognah* (iD, Fatma Soltan, Haneen Azzuz, Khaled Elhenshiri \\ Department of Endodontics and Conservative Dentistry Faculty of Dentistry, University of Tripoli, Tripoli, Libya. \\ Corresponding Email: asma.abognah@gmail.com
}

\begin{abstract}
Whatever the technique used for root canal instrumentation; a layer of debris termed "smear layer" is formed. This is a layer composed of an organic and inorganic substance and it harbors bacteria and their by-products. Removing the smear layer enhances the cleaning and disinfecting of root canal walls and grant maximum adaptation of root canal filling materials. Nonetheless, the existence of smear layer can seal the dentinal tubules and decrease the probability of dentinal tubule's invasion by bacteria and their toxins, this issue is still controversial. Smear layer removal approaches including chemical, ultrasonics, and laser have been widely studied. However, none of them is entirely efficient along the length of all canals or is universally recognized. If the decision was to remove smear layer, irrigating root canals with EDTA followed by $\mathrm{NaOCl}$ will fulfill the objective. It is still debatable whether the removal of smear layer will decrease the apical leakage or not. Additional research is required to determine the consequence of removing or preserving the smear layer.
\end{abstract}

Keywords: Endodontic treatment- Smear Layer- EDTA- Ultrasonics- Laser

Citation: Abognah A, Soltan F, Azzuz H, Elhenshiri K. Smear Layer in Endodontics: A review of its role and management. Khalij-Libya J Dent Med Res. 2020;4(2):38-50. https://doi.org/10.5281/zenodo.4018006

Received: 20/08/20; accepted: 07/09/20

Copyright (C) Khalij-Libya Journal (KJDMR) 2020. Open Access. Some rights reserved. This work is available under the CC BY-NC-SA 3.0 IGO license https://creativecommons.org/licenses/by-nc-sa/3.0/igo

\section{INTRODUCTION}

The main objective of endodontic treatment is to reduce the number of microorganisms within the root canal system followed by competent obturation. This cannot be achieved without a proper shaping of the root canal system to create a smooth, tapering canal, which can be easily and quickly obturated [1].

The use of either hand or rotary and reciprocating instruments to shape the root canal space creates a substantial amount of dentinal debris that is called smear layer. At first, it was reported in the literature that smear layer consists of dentin chips, cell debris, and pulp remnants [2], this layer extended few micrometers within dentinal tubule [3]. Smear layer has two separate layers: a loose, superficial deposit and an attached layer that extends into the dentinal tubules, forming occluding plugs [4].

Researches has been conducted evaluating the quality of the smear layer $[5,6]$, and its thickness which found to range from $1-5 \mu \mathrm{m}[3,7,8]$. There is a variation between the penetration depth of the smear layer into dentinal tubules and its thickness depending on many 
factors such as capillary action between dentinal tubules and debris $[9,10]$, the type and sharpness of cutting instruments and dentin humidity [11].

Some authors have found that the quantity of smear layer formed by engine-driven instruments such as Gates-Glidden drills is greater than that formed by hand filing [12]. Furthermore, the composition of this layer is a combination of organic and inorganic substances where the organic substance such as necrotic pulp tissue is located deeper toward the canal wall, increasing the instrumentation force will result in deposition of a thicker layer of inorganic substance, which is more resistant to the removal with chelating agents [13].

Formation of the smear layer is unavoidable during root canal instrumentation; this is why it is not found in areas that are unprepared. Based on this concept, studies used the non-instrumentation technique, which relies on active irrigation, produces excellent canal cleaning [14]. However, initial clinical studies stated that this system needs improvement before using it routinely for root canal cleaning [15].

\section{Clinical implication of the smear layer}

Understanding the condition of the diseased pulp is essential before evaluating the influence of smear layer on the treatment outcome. The presence of numerous bacterial species, their toxins, and byproducts has been declared as the main cause of root canal pathology. These bacteria are mostly gramnegative anaerobic [16]. In addition, it has been shown that root canal complexity leads to non-accessible areas that are difficult to clean mechanically. The size and density of dentinal tubules are different along the root surface, they estimated to be 15,000 per square millimeter at the cement-enamel junction [17].

Researchers had meticulously studied the existence of bacteria and their toxins within dentinal tubules of infected roots; the depth of penetration of bacteria has reached one-half of the distance between the root canal wall and the cement-dentinal junction. The number and the type of bacteria as well as the length of exposure play an important role in determining the depth of penetration of bacteria [18].

Additionally, the presence or absence of the smear layer is a major contradicting point in the literature. Different conclusions regarding removing or leaving the smear layer has been reached. Those who are against its removal claimed that smear layer removal will expose more dentinal tubules leading to deeper bacterial penetration [19-21].

Darke, et al. claimed that when smear layer is removed, bacteria would colonize in a higher depth within the dentinal tubules compared with roots with an intact smear layer [16]. Pashley declared if the canals were partially cleaned, smear layer would prevent bacteria from penetrating the dentinal tubules to a deeper level [22]. However, Williams and Goldman [23] reported that this layer cannot act as a complete barrier and its presence would only delay bacterial invasion. The inability of all previous studies to simulate the clinical environment was a major limitation.

Another group of researchers is in favour of removing the smear layer. It is established that smear layer contains necrotic tissue, bacteria, and its by-products that causing more irritation and may provide microorganisms with resources to survive, multiply, and proliferate deeply inside the dentinal tubules [24]. Although several studies reported that removal of smear layer will allow more cleaning and removing microorganisms [25-27]. Furthermore, the presence of smear layer decreases the level of penetration of disinfectant solutions into dentinal tubules [4], and minimizing the ability of intracanal medications to disinfect the canal properly [7]. 
In addition, some studies have stated that smear layer has a drawback on the ability of the sealer to penetrate into dentinal tubules [28], which reduces the ability of gutta-percha to adapt to canal walls properly [29]. All these may lead to unsatisfactory coronal and apical seal causing bacterial leakage, which results in alteration of the root canal treatment outcome. Therefore, researchers strongly recommend that smear layer must be removed in order to obtain a satisfactory treatment outcome.

\section{Effect of smear layer on the penetration and bonding efficiency of different sealing materials}

As stated before, the significant objective of endodontic treatment is to obtain the hermetic filling of the root canal system, which is achieved by complete, tri-dimensional sealing of the root canal system, helping in preventing microorganisms and their products from invading root canal system, through the coronal and apical pathways [30,31].

Chemo-mechanical preparation usually produces debris-free root canals, which can be safely filled later. Nevertheless, thorough cleaning of the root canal system may not be accomplished due to smear layer deposition [32]. The effect of this layer on root canal treatment prognosis is unknown [33], but the thing which is known is that it can be degraded by bacterial toxins and acids [34], which allows a pathway to form, through which leakage could occur [35].

Gutta-percha is used routinely with root canal sealer to obtain a fluid-tight seal. Root canal sealers fill the voids between gutta-percha points and between gutta-percha and root canal walls [31]. Inadequate obturation of the root canal significantly contributes to the failure of endodontic therapy [36].

Leakage in root canals is the passage of bacteria and fluids between the tooth and the root canal filling material. The space between the tooth and the filling material may result from insufficient adaptation of the filling material to the root canal walls, cements solubility, expansion or shrinkage. Leakage occurs at one of two aspects: at the interface between the guttapercha and the cement or between the cement and root canal walls [37].

Microleakage along the root canal obturation may occur between gutta-percha and sealer, through voids within the sealer, or between the sealer and dentin. Therefore, the quality of the root canal filling and the success rate of endodontic treatment depend greatly on the sealing ability of a root canal sealer [38].

There has been a strong interest in the potential implications of the smear layer on leakage of obturated root canals. Various studies have evaluated apical and coronal leakage in the presence or absence of the smear layer; however, there is no consensus among researchers as to whether the smear layer is associated with more leakage in obturated canals [37, 39]. Smear layer removal created mechanical interlocking of sealer plugs inside tubules, which could enhance the sealing ability of the material. The bond strength between some sealers and dentin improved when the smear layer was left intact [38].

Whether to maintain the smear layer before endodontic filling or not, continues to be a controversial subject. Many authors consider that it is favorable to maintain it as it fills the dentinal tubule entrances, thus reducing dentin permeability [38]. Others foresee difficulties if it remains because it prevents medications from penetrating into the root canal walls and dentinal tubules [4]. Moreover, it acts as a barrier between the filling materials and root canal walls, interfering in the formation of appropriate sealing [38]. Therefore, any factors that may influence the adaptation of the filling material to the root canal wall are of great importance in determining the depth and extent of leakage, and finally, the prognosis of endodontic therapy. 
At present, there has been great interest in investigating the possible effect of smear layer removal on endodontic leakage. Nevertheless, there is no agreement about its actual influence on effective sealing of the root canal system [31]. Some researchers have declared that the presence or absence of the smear layer has no major impact on the sealing of root canal fillings [40,41]. Whereas others, such as Kont Çobankara et al. [31], Gençoglu et al. [42], Taylor et al. [43], Economides et al.[44] and Kokkas et al [45] affirmed that its removal produces a positive effect on sealing, as it enables the cement to penetrate into the dentinal tubules, promoting better adaptation of the filling materials to the root canal walls.

Moreover, several authors have reported that maintaining the smear layer could reduce leakage. They considered that the smear layer could diminish dentinal permeability and prevent the bacterial infiltration into the dentin [38].

\section{Methods of Smear Layer removal}

Irrigation materials are been routinely used root canal treatment. Root canal disinfectant is mandatory to ensure successful root canal treatment. Canal disinfection requires chemical preparation as well as mechanical preparation. Canal disinfection substantially relies on irrigants because of the anatomic complexities of the pulp canal system [46]. Mechanical preparation will result in smear layer formation and chemical preparation will disinfect the parts that cannot be reached mechanically [47].

The most frequently used irrigant solution in endodontic treatment is Sodium hypochlorite $(\mathrm{NaOCl})$. It is potently antimicrobial and dissolves organic material pulp tissue) within the root canal. Meanwhile, it lacks the capability to eliminate the smear layer [48].
Chlorhexidine is a substantive antimicrobial irrigant (continued antimicrobial effect because $\mathrm{CHX}$ binds to hard tissue). Unfortunately, it cannot dissolve pulp tissue; therefore, it cannot substitute sodium hypochlorite. It has no effect on smear layer as well [49].

A chelating agent such as EDTA would bind to the calcium ion in the hydroxyapatite crystals of dentin and subsequently demineralize dentin. The chelating agent's efficiency relies on various factors including application time, $\mathrm{pH}$, concentration, and amount of the solution [50].

EDTA (Ethylenediaminetetraacetic acid) is a chelating agent. EDTA solution is neutral or slightly alkaline; EDTA will precipitate at acidic ph. It has no antibacterial effect but it confines the growth and kills microbes by chelating with some metallic ions essential for its growth [51].

EDTA is available in a $17 \%$ or $15 \%$ solution. Even $1 \%$ EDTA solution is powerful enough to remove smear layer, as some studies have suggested. Application of 17\% EDTA subsequent to cleaning and shaping highly advised to remove the smear layer before root canal obturation. EDTA reacts with dentin's calcium ions resulting in soluble calcium chelates formation. EDTA decalcifies dentin to an extent of $20-30 \mu \mathrm{m}$ in $5 \mathrm{~min}$ [52]. The appropriate time for EDTA application to remove smear layer is about two minutes, but the thicker the smear layer is, the longer time of exposure should be [46].

MTAD (Mixture tetracycline citric acid and detergent) is a potent intracanal irrigant in regards to smear layer removal. It is a mixture of a $3 \%$ doxycycline antibiotic, a chelating agent $4.5 \%$, citric acid and detergent. It does not change the dentinal tubules structure and it is recommended to be used as a final rinse [53].

QMix is a recent irrigating solution introduced to remove the smear layer and kill microorganisms. It is 
composed of EDTA, chlorhexidine (CHX), and a detergent. Stojicic et al. claimed that alternating between $\mathrm{NaOCl}$ and QMix had a greater antimicrobial action compared to CHX and MTAD and removed the smear layer more efficient [54].

Citric acid is an organic acid. It is highly effective in removing the inorganic component of the smear layer, better than polyacrylic acid, lactic acid. It is used at varying concentrations from $1 \%$ to $50 \%$ but with a $10 \%$ solution has the best effect in eliminating the smear layer. It can be used for 2-3 min when instrumentation has been completed and after irrigation with $\mathrm{NaOCl}$ [50].

When EDTA is used in combination with $\mathrm{NaOCl}$, both the inorganic and the organic elements are removed, resulting in a clean surface and opened dentinal tubules to the level of the apical part [55]. However, the reaction between EDTA and $\mathrm{NaOCl}$ can reduce the amount of chlorine available, thereby compromising the tissue dissolving ability and antimicrobial effect of $\mathrm{NaOCl}$ [56]. To overcome this problem, copious amount of $\mathrm{NaOCl}$ must be applied to washout remnants of EDTA [57]. In addition, the use of water in between irrigants will help to reduce the interaction between different chemicals inside root canals [58].

\section{Ultrasonic smear layer removal}

Richman first implemented the concept of using ultrasonics "US" in endodontics in 1957. However, Martin et al. established their use by demonstrating the ability of ultrasonically activated K-files to cut dentin, so their use for root canal preparation becomes common $[59,60]$.

There are two types of units: Ultrasonic devices, which run at 25 to $30 \mathrm{KHz}$, and sonic devices or so-called low-frequency ultrasonic handpieces operating from 1 to $3 \mathrm{KHz}$. Currently, ultrasonics used in non-surgical as well as surgical endodontics; one of these applications is $\mathrm{NaOCl}$ activation by an ultrasonic delivery system [61].

The use of irrigation in conjunction with ultrasonic vibration, which elicits a persistent movement of the irrigant is directly associated with the effectiveness of cleaning of the root canal space [61, 62]. Furthermore, it has been found that ultrasonic irrigation is more effective with greater tapered root canals so, it is important to apply ultrasonic irrigation after the preparation of root canals has been completed [63]. Researchers have found that ultrasonically energized full strength $\mathrm{NaOCl}$ did not eliminate the smear layer from root canal walls [64], however, when ultrasonic removal of smear layer was evaluated using 15\% EDTA with either distilled water or $1 \%$ sodium hypochlorite a satisfactory results were achieved [65]. Another study evaluated the efficacy of passive ultrasonic irrigation (PUI) with 17\% EDTA and 1\% $\mathrm{NaOCl}$ solutions on smear layer removal. In this study, a comparison of the quantity of smear layer that was removed among apical, middle, and cervical thirds within the tested samples has been performed. It was found that the cervical third of the samples from all groups showed a higher percentage of smear layer removal and open dentinal tubule areas, followed by the middle and apical thirds. As a result, using 1\% $\mathrm{NaOCl}$ and ultrasonic tip placed within $1 \mathrm{~mm}$ of the apical foramen did not show higher efficacy in smear layer removal compared with conventional irrigation [66].

Furthermore, the influence of US with different final irrigants in intracanal smear layer removal, using scanning electron microscopy (SEM) was investigated [67]. In this study, the tested substances were $17 \%$ EDTA, QMix, 10\% citric acid and 37\% phosphoric acid solution. Based on the outcomes of the present study, the use of US with the four tested chelating agents in the cervical third did not enhance the smear layer removal capacity compared with groups where US 
was not used. In the middle third, groups $(17 \%$ EDTA+US) and (QMix+ US) have shown a higher ability to promote smear layer removal compared with all other groups. However, in the apical third, the group (QMix+US) has shown a greater ability to promote smear layer. These findings comply with previous studies, which stated that smear layer removal enhanced with the adjunctive use of ultrasonic irrigation $[68,69]$.

Considering such results, it is believed that ultrasonic activation can aid 17\% EDTA and QMix in smear layer removal, leading to better cleaning of root canal, since superior outcomes were found for 17\% EDTA and QMix in the middle third, and for QMix in the apical third when ultrasonic activation of these substances was executed. However, there is some issue regarding the effect of using 17\% EDTA with US on increasing dentinal erosion [70,71]. A recent study has confirmed these results and showed that PUI with both $17 \%$ EDTA and QMiX as final irrigants improved the removal of debris/smear layer in the middle and apical thirds of the root canal when compared to CI [72]. Cameron assessed the effect of increasing the time on the ability of the ultrasonic activation to ensure smear free canal walls [73]. He concluded that 3-5 min of ultrasonic activation of the irrigant was better than $1 \mathrm{~min}$. Moreover, a study by Ahmetoglu et al. (2014) investigated the effectiveness of different irrigation devices like passive ultrasonic irrigation, apical negative pressure irrigation (EndoVac), and conventional needle irrigation systems on smear layer removal. They founded that the irrigating solution used is more significant rather than the system used [74]. These results were recently supported by a systematic review and meta-analysis conducted by Virdee et al (2018) who founded that despite the fact ultrasonic irrigation improves intracanal cleanliness and smear layer removal in relation to conventional needle irrigation, no individual technique showed superiority than another [75]. Therefore, it can be concluded that passive ultrasonic irrigation (PUI) can improve debris and smear layer removal and sealer penetration into the dentinal tubules. However, factors such as final irrigating solution, technique used for irrigation, root canal thirds, must be taken into consideration.

\section{Using laser to remove smear layer}

Using laser in endodontics began in the early seventies with Weichman and Johnson and Lenz (1971, 1972, 1974) [76-78], but were mainly developed from the early 1990s onward. It was used as an assistant protocol in order to enhance the results of traditional procedures. Several factors influence the effectiveness of lasers, including the power level, the exposure time, the absorption of light in the tissues, the configuration of the root canal and the tip-to-target distance. Studies have been performing on different laser systems available at that time such as neodymium: yttrium-aluminum-garnet (Nd: YAG) and carbon dioxide (CO2) lasers. The diode laser is recommended for endodontic treatment because its wavelength is within the infrared range and its thin and flexible fibers help to remove the smear layer. At the beginning of the 1990s, with the introduction of pulsed technology for $\mathrm{Nd}$ : YAG lasers with optical fibers [79], the research was focused on decontamination and cleansing of the smear layer and organic remnants of root canals [79-86].

Harashima et al. (1997) [87], Koba et al. (1998) [88], and Santos et al. (2005) [89] Studied the effect of Nd:YAG laser at different power settings and time on the cleaning and decontamination of root canal. All of these in-vitro studies showed incomplete removal of smear layer. Santos et al. (2005) evaluated with SEM observations the effect of different parameters and radiation angles of $\mathrm{Nd}$ :YAG laser on the morphology of radicular dentin. 
Parameters that are more elevated developed more morphological alterations of the dentin surface, and superior removal of smear layer with cleaner surface. In addition, samples that received the irrigation with $17 \%$ EDTA before irradiation showed dentinal tubules more opened. He et al. (2009) studied the rise in temperature at the coronal and apical levels at different power settings of Nd: YAG laser, superior results (removal of the smear layer, open dentinal tubules, rise of temperature in the acceptable limits) were obtained at $2 \mathrm{~W}(20 \mathrm{~Hz}, 100 \mathrm{~mJ})$ [90].

Hasheminia et al. (2012) also established the partial removal of the smear layer in the samples irradiated with the Nd: YAG laser and the superior efficacy of irrigants such as sodium hypochlorite [91]. Takeda et al. (1999) supported the use of erbium:YAG (Er:YAG) laser to remove the smear layer [92]. It resulted in effective smear layer removal without causing any side effect to the dentin; melting, charring, or vaporization that can be associated with other types of laser. Kimura et al. (2002) confirmed the positive effect of using Er:YAG laser on the smear layer [93]. However, Kivanc et al. (2008), compared in SEM study the effects of Nd:YAG and Er:YAG laser irradiation on radicular dentin, concluded that neither wavelength was efficient in removing the smear layer and debris from the canal walls [94]. Many studies have investigated the role of photo-activated disinfection as an adjunct to conventional irrigation for root canal disinfection. On the other hand, some researchers have focused on the ability of laser-activated irrigation (LAI) to improve smear layer removal [95-103]. De Moor et al. (2009) completed their first study comparing the efficacy of LAI for removal of debris in root canals to conventional irrigation (CI) and passive ultrasonic irrigation (PUI) for just $20 \mathrm{~s}$ at a frequency of $30 \mathrm{KHz}$ and. An Er,Cr:YSGG laser, equipped with a $200 \mu \mathrm{m}$ flat tip, was used at $75 \mathrm{~mJ}, 20 \mathrm{~Hz}, 1.5 \mathrm{~W}$ to activate $2.5 \% \mathrm{NaOCl}$ four times for $5 \mathrm{~s}$, placed fixed at $5 \mathrm{~mm}$ from the apical stop, prepared at ISO 40. LAI resulted in statistically significantly less debris than PUI $(\mathrm{P}<0.005)$ and CI $(\mathrm{P}<0.0005)$, both during $20 \mathrm{~s}$ [97]. Another study found that increasing time up to 60s using Er,Cr:YSGG laser results in complete removal of smear layer [99].

In a study by Bolhari et al. (2014), the quality of smear layer and debris removal in the three segments of the root canal were investigated comparing an EDTA and $\mathrm{NaOCl}$ final rinse protocol (G1), Er,Cr:YSGG irradiation $1.5 \mathrm{~W}$ (G2), and 2.5 W (G3). The findings indicated no significant differences between groups 1 and 2 regarding the quality of smear layer removal in all areas while irradiation at $2.5 \mathrm{~W}$ failed to remove the smear layer effectively. In this study, better cleaning efficacy was noted in the coronal and middle third when relying on laser-activated irrigation of EDTA [101]. Suman et al. (2017) declared that using EndoActivator, EndoVac, and Er: YAG laser increases the smear layer removing efficiency at the apical and the middle third. However, in this study, EndoVac and EndoActivator performed better than Er: YAG laser at apical third [102]. These findings were supported by Mancini et al. (2018) who concluded that none of the activation/delivery systems tested entirely removed the smear layer from the root canal walls; nevertheless, EV and EA showed, respectively, statistically significant better results that LAI apically [103]. The reason why EV showed better results may be due to the negative pressure it creates in the canal, which takes the irrigant to the full working length.

Recently, a new technique of laser application is introduced in endodontics, which is Photon-induced photoacoustic streaming. (PIPS) is an advanced laseractivated irrigation process by which photons of light are released at very low energy levels and with short microsecond pulse duration. Unlike other forms of laser-activated irrigation, PIPS utilize a unique tapered and stripped tip design that allows for lateral diffusion and transmission of the generated wave in 
liquids. This can reduce the risk of thermal damage and allows for effective three-dimensional streaming when the specific parameters and procedure are used.

The main difference between PIPS and other LAI techniques is that PIPS technique is based on new "minimally invasive" or "biomimetic" concept that requires less intracanal instrumentation without compromising the ability for irrigation to effectively reach all aspects of the root canal system; this could enhance the conservation of dentin structure and reduces the possibility of laser thermal damage as well as creating greater cleaning and decontamination [104].

Uses of $17 \%$ EDTA activated by PIPS during the irrigation protocol and after mechanical instrumentation resulted in better cleaning and smear layer removal when compared to other irrigation techniques $[105,106]$. Further studies have supported these findings and confirmed that the best results were obtained when PIPS used in combination with $17 \%$ EDTA [107-110].

\section{CONCLUSION}

Root canal instrumentation produces a smear layer that covers the surfaces of prepared canal walls. This smear layer is a combination of inorganic and organic substances in addition to microorganisms and necrotic debris. There is a lack of agreement regarding preserving or removing the smear layer based on whether it has a beneficial or an adverse effect on the treatment outcome. However, if the decision to be removed was made, the alternate use of sodium hypochlorite $(\mathrm{NaOCl})$, a deproteinizing agent, and ethylenediaminetetraacetic acid (EDTA), a calciumchelating agent, has been recommended for its efficient removal. These irrigants must contact directly with the entire canal wall with different irrigation techniques for effective action. Extensive studies are available within endodontic literature evaluating the efficiency of different techniques for smear layer removal. The main limitation of these studies was that they did not exactly simulate the clinical conditions of root canal treatment. Therefore, extensive research is required in the future on advanced irrigation techniques with clinically relevant models to determine the effect of the presence or absence of the smear layer on bacterial colonization of root canals.

Recently, new sealer and filling materials have been introduced; therefore, further researches are necessary to find out the interaction between these materials and smear layer as well as their effect on the treatment outcome. Moreover, it is also important to understand the change that occurs to the root dentin after the application of chelating agent.

\section{Disclaimer}

The article has not been previously presented or published, and is not part of a thesis project.

\section{Conflict of Interest}

There are no financial, personal, or professional conflicts of interest to declare.

\section{REFERENCES}

1. Schilder H. Filling root canals in three dimensions. J Endod, 2006; 32: 281-290.

2. Eick JD, Wiko RA, Andreson $\mathrm{CH}$, Sorensen SE. Scanning electron microscopy of cut tooth surfaces and identification of debris by using the electron microprobe. J Dent Res, 1970; 49(suppl): 1359-68.

3. Brännström $M$, Johnson G. Effects of various conditioners and cleaning agents on prepared dentin surfaces: A scanning electron microscopic investigation. J Prosthet Dent, 1974; 31:422-30.

4. McComb D, Smith DC. A preliminary scanning electron microscopic study of root canals after endodontic procedures. J Endod, 1975; 1(7):238-242. 
5. Lester KS, Boyde A. Scanning electron microscopy of instrumented, irrigated and filled root canals. Br Dent J, 1977; 143: 359-67.

6. Goldman LB, Goldman M, Kronman JH, Lin PS. The efficacy of several irrigating solutions for endodontics: A scanning electron microscopic study. Oral Surg Oral Med Oral Pathol, 1981; 52:197-204.

7. Brännström $\mathrm{M}$, Nordenvall KJ, Glantz PO. The effect of EDTA-containing surface-active solutions on the morphology of prepared dentin: An in vivo study. J Dent Res, 1980; 59: 1127-31.

8. Mader CL, Baumgartner JC, Peters DD. Scanning electron microscopic investigation of the smeared layer on root canal walls. J Endod, 1984; 10: 477-83.

9. Cameron JA. The use of ultrasonics in the removal of the smear layer: A scanning electron microscope study. J Endod, 1983; 9: 289-92.

10. Aktener BO, Cengiz T, Piskin B. The penetration of smear material into dentinal tubules during instrumentation with surface-active reagents: a scanning electron microscopic study. JOE, 1989; 15: 588-90.

11. Cameron JA, The use of ultrasound for the removal of the smear layer. The effect of sodium hypochlorite concentration; SEM study. Aust Dent J, 1988; 33, 193200.

12. Jodaikin A, Austin JC: Smear layer removal with chelating agents after cavity preparation. J Prosthet Dent, 1981; 46: 171-4.

13. Pashley DH, Tao L, Boyd L, King GE, Horner JA. Scanning electron microscopy of the substructure of smear layers in human dentine. Arch Oral Biol 1988; 33:265-70.

14. Lussi A, Nussbacher U, Grosrey J, A novel noninstrumental technique for cleansing the root canal system. J Endodon, 1993; 19: 549.

15. Attin T, Buchalla W, Zirkel C, Lussi A, Clinical evaluation of the cleansing properties of the noninstrumental technique for cleaning root canals. Int Endod J, 2002; 35: 929.

16. Drake DR, Wiemann AH, Rivera EM, Walton RE. Bacterial retention in canal walls in vitro: effect of smear layer. JOE, 1994; 20: 78-82.17.
17. Davis RD, Marshall JG, Baumgartner JC, Effect of Early Coronal Flaring on Working Length Change in Curved Canals Using Rotary Nickel-Titanium Versus Stainless Steel Instruments. J Endod. 2002; 28(6):43842.

18. Violich DR, Chandler NP. The smear layer in endodontics - a review. Int Endod J, 2010; 43: 2-15.

19. Michelich VJ, Schuster GS, Pashley DH. Bacterial penetration of human dentin in vitro. J Dent Res 1980; 59:1398-403.

20. Pashley DH, Michelich V, Kehl T. Dentin permeability: Effects of smear layer removal. J Prosthet Dent 1981; 46: 531-7.

21. Safavi KE, Spangberg LS, Langeland K. Root canal dentinal tubule disinfection. J Endod, 1990; 16: 207-10.

22. Pashley DH. Dentin-predentin complex and its permeability: Physiologic overview. J Dent Res, 1985; 64: 613-20.

23. Williams S, Goldman M. Penetrability of the smeared layer by a strain of Proteus vulgaris. J Endod 1985; 11: 385-8.

24. George S, Kishen A, Song KP. The role of environmental changes on monospecies biofilm formation on root canal wall by Enterococcus faecalis. J Endod, 2005; 31: 867-72.

25. Bystrom A, Sundqvist G. The antibacterial action of sodium hypochlorite and EDTA in 60 cases of endodontic therapy. Int Endod J, 1985;18: 35-40.

26. Brännström $M$. Communication between the oral cavity and the dental pulp associated with restorative treatment. Oper Dent, 1984; 9:57-68.

27. Outhwaite WC, Livingston MJ, Pashley DH. Effects of changes in surface area, thickness, temperature and post-extraction time on human dentine permeability. Arch Oral Biol, 1976; 21: 599-603.

28. Okşan T, Aktener BO, Sen BH, Tezel H. The penetration of root canal sealers into dentinal tubules. A scanning electron microscopic study. Int Endod J 1993;26:301-5.

29. Gençoğlu N, Samani S, Günday M. Evaluation of sealing properties of Thermafil and Ultrafil ${ }^{\circledR}$ techniques in the absence or presence of smear layer. J Endod, 1993;19:599-603. 
30. Silva-Neto UX, Moraes IG, Westphalen VPD, Menezes R, Carneiro E, et al. Leakage of 4 resin-based root-canal sealers used with a single cone technique. Oral Sur, Oral Med, Oral Patho, Oral Radio. 2007; 104: 53-57.

31. Kont-Çobankara F, Adanir N, Belli S. Evaluation of the influence of smear layer on the apical and coronal sealing ability of two sealers. JOE, 2004; 30: 406-409.

32. SenBH, Wesselink PR, Turkun M. The smear layer: a phenomenon in root canal therapy. Int Endod J.1995; 28: 141-148.

33. Czonstkowsky M, Wilson EG, Holstein FA. The smear layer in endodontics. Dental Clinics of North America. 1990; 34: 13-25.

34. Meryon SD, Brook AM. Penetration of dentine by three oral bacteria in vitro and their associated cytotoxicity. Int Endod J. 1990; 23: 196-202.

35. Pitt Ford TR, Roberts GJ. Tissue response to glass ionomer retrograde root fillings. Int Endod J,1990; 23: 233-238.

36. Fisher M A, Berzins D W, Bahcall J K. An In Vitro comparison of bond strength of various obturation materials to root canal dentin using a push-out test design. JOE, 2007; 33: 856-858.

37. Timpawat S, Vongsavan N, Messer H. Effect of removal of smear layer on apical microleakage. JOE. 2001; 27: 351-353.

38. Perin, C.P., Neto, U.X., Westphalen, V.P., Alice., Santos, H., Leão, B.L., \& Mattos, N.H. Evaluation of the influence of smear layer removal on the apical leakage: in vitro study. OHDM, 2018; 17.

39. Wu M-K, De Gee AJ, Wesselink PR, Moorer WR. Fluid transport and bacterial penetration along root canal fillings. Int Endod J. 1993; 26: 203-208.

40. Park DS, Torabinejad M, Shabahang S. The effect of MTAD on the coronal leakage of obturated root canals. JOE. 2004; 30: 890-892.

41. Shemesh $\mathrm{H}, \mathrm{Wu}$ MK, Wesselink PR. Leakage along apical root fillings with and without smear layer using two different leakage models: a two month longitudinal ex vivo study. Inter Endod J. 2006; 39: 968-976.

42. Gençoglu N, Samani S, Gunday M. Evaluation of sealing properties of thermafil and ultrafil techniques in the absence or presence of smear layer. JOE. 1993; 12: 599-503.

43. Taylor J, Jeansonne BG, Lemon RR. Coronal leakage: effects of smear layer, obturation technique, and sealer. JOE. 1997; 8: 508-512.

44. Economides N, Kokorikos I, Kolokouris I, Panagiotis B, Gogos C. Comparative study of apical sealing ability of a new resinbased root canal sealer. JOE. 2004; 6: 403-405.

45. Kokkas B, Boutsioukis AC, Vassiliadis LP, Stavrianos $\mathrm{K}$. The influence of the smear layer on dentinal tubule penetration depth by three different root canal sealers: an in vitro study. JOE. 2004; 2: 100-102.

46. Wang H, Sanabria-Liviac D, Sleiman P, Dorn S, Jaramillo D. Smear layer and debris removal from dentinal tubules using different irrigation protocols: scanning electron microscopic evaluation, an in vitro study. Evidence-Based Endod 2017; 2: 1186-41121.

47. Torabinejad M, Handysides R, Khademi AA, Bakland LK. Clinical implications of the smear layer in endodontics: a review. Oral Surg Oral Med Oral Pathol Oral Radiol Endod. 2002; 94: 658-66.

48. Haapasalo M, Shen $Y$, Wang Z, Gao Y. Irrigation in endodontics. Br Dent J. 2014 Mar; 216(6):299-303.

49. Mohammadi Z \& Abbott PV. Antimicrobial substantivity of root canal irrigants and medicament: A Review. Aust Endod J 2009; 35: 131-139.

50. Darrag AM. Effectiveness of different final irrigation solutions on smear layer removal in intraradicular dentin. Tanta Dent J 2014; 11(2): 93-99.

51. Alamoudi RA. The smear layer in endodontic: To keep or remove - an updated overview. Saudi Endod J 2019; 9: 71-81.

52. Mohammadi Z, Shalavi S, Jafarzadeh $H$. Ethylenediaminetetraacetic acid in endodontics. Eur J Dent. 2013;7(suppl):135-142.

53. Torabinjad M, Cho Y, Khademi AA, Bakland LK, Shabahang S. The Effect of Various Concentrations of Sodium Hypochlorite on the Ability of MTAD to Remove the Smear Layer. J Endod. 2003; 29(4): 233239.

54. Stojicic S, Shen Y, Qian W, Johnson B, Haapasalo M. Antibacterial and smear layer removal ability of a novel irrigant, QMiX. Int Endod , 2012;45:363-71. 
55. Yamada RS, Armas A, Goldman M, Lin PS. A scanning electron microscopic comparison of a high volume final flush with several irrigating solutions: Part 3. J Endod. 1983;9(4):137-142.

56. Grawehr M, Sener B, Waltimo $T$, Zehnder M. Interactions of ethylenediaminetetraacetic acid with sodium hypochlorite in aqueous solutions. Int Endod J. 2003;36(6):411-417.

57. Zehnder M. Root canal irrigants. J Endod. 2006;32(5):389-398.

58. Prado M, Simao R, Gomes B. Evaluation of different irrigation protocols concerning the formation of chemical smear layer. Micros Res tech. 2013; 76(2): 196-200.

59. Richman RJ. The use of ultrasonics in root canal therapy and root resection. Med Dent J, 1957; 12:12-8.

60. Martin H, Cuningham WT, Norris JP, Cotton WR. Ultrasonic versus hand filing of dentin: a quantitative study. Oral Surg Oral Med Oral Pathol, 1980; 49:79-8.

61. Ahmad M, Pitt Ford TJ, Crum LA. Ultrasonic debridement of root canals: Acoustic streaming and its possible role. J Endod, 1987;13: 490-9.

62. Krell KV, Johnson RJ, Madison S. Irrigation Patterns During Ultrasonic Canal Instrumentation. Part I. Ktype Files. J Endod. 1988; 14(2):65-8.

63. Van der Sluis LW, Versluis M, Wu MK, Wesselink PR. Passive Ultrasonic Irrigation of the Root Canal: A Review of the Literature. Int Endod J, 2007; 40(6): 41526.

64. Baumgartner JC, Cuenin PR . Efficacy of Several Concentrations of Sodium Hypochlorite for Root Canal Irrigation. J Endod. 1992; 18 (12): 605-12.

65. Guerisoli DM, Marchesan MA, Walmsley AD, Lumley PJ, Pecora JD. Evaluation of smear layer removal by EDTAC and sodium hypochlorite with ultrasonic agitation. Int Endod J, 2002; 35:418-21.

66. Schmidt TF, Teixeira CS, Felippe M, Felippe WT, Pashley DH, Bortoluzzi EA. Effect of Ultrasonic Activation of Irrigants on Smear Layer Removal. J Endod, 2015; 41(8):1359-63.

67. Souza1MA, Motter FT, Fontana1 TP, Ribeiro MP, Miyagaki DC, Cecchin D. Influence of ultrasonic activation in association with different final irrigants on intracanal smear layer removal. Braz J Oral Sci, $2016 ; 15(1)$.

68. Caron G, Nham K, Bronnec F, Machtou P. Effectiveness of different final irrigant activation protocols on smear layer removal in curved canals. J Endod. 2010; 36(8):1361-6.

69. Blank-Gonçalves LM, Nabeshima CK, Martins GH, Machado ME. Qualitative analysis of the removal of the smear layer in the apical third of curved roots: conventional irrigation versus activation systems. J Endod. 2011; 37(9):1268-71.

70. Qian W, Shen Y, Haapasalo M. Quantitative analysis of the effect of irrigant solution sequences on dentin erosion. J Endod. 2011; 37(10):1437-41.

71. Aranda-Garcia AJ, Kuga MC, Chavéz-Andrade GM, Kalatzis-Sousa NG, Hungaro Duarte MA, Faria G, et al. Effect of final irrigation protocols on microhardness and erosion of root canal dentin. Microsc Res Tech. 2013; 76 (10):1079-83.

72. De Souza Matos F, Da Silva FR, Paranhos LR, Moura CC, Bresciani E \& Valera MC. The efect of $17 \%$ EDTA and QMiX ultrasonic activation on smear layer removal and sealer penetration: ex vivo study. Sci Rep, 2020; 10: 10311.

73. Cameron JA. The use of ultrasonics in the removal of the smear layer: A scanning electron microscope study. J Endod, 1983;9: 28992.

74. Ahmetoglu F, Keles A, Yalcin M, Simsek N. Effectiveness of different irrigation systems on smear layer removal: A scanning electron microscopic study. Eur J Dent, 2014; 8:53-7.

75. Virdee SS, Seymour DW, Farnell D, Bhamra G, Bhakta S. Efficacy of irrigant activation techniques in removing intracanal smear layer and debris from mature permanent teeth: A systematic review and meta-analysis. Int Endod J, 2018; 51: 605-21.

76. Weichman JA, Johnson FM. Laser use in endodontics. A preliminary investigation. Oral Surg Oral Med Oral Pathol. 1971; 31(3):416-20.

77. Weichman JA, Johnson FM, Nitta LK. Laser Use in Endodontics. II. Oral Surg Oral Med Oral Pathol, 1972; 34(5):828-30.

78. Myers TD. Lasers in dentistry. CDS Rev. 1991; 84(8):26-9. 
79. Gutknecht N, Behrens VG. Instrumentation of root canal walls with Nd-YAG laser. ZWR. 1991;100(10): 748-50, 752, 755.

80. Levy G. Cleaning and shaping the root canal with a Nd:YAG laser beam: a comparative study. J Endod. 1992; 18(3):123-7.

81. Bahcall JK, Miserendino L, Walia H, Belardi DW. Scanning electron microscopic comparison of canal preparation with Nd:YAG laser and hand instrumentation: a preliminary study. Gen Dent. 1993;41(1):45-7.

82. Goodis HE, White JM, Marshall SJ, Marshall Jr GW. Scanning electron microscopic examination of intracanal wall dentin: hand versus laser treatment. Scanning Microsc. 1993;7(3):979-87.

83. Hardee MW, Miserendino LJ, Kos W, Walia H. Evaluation of the antibacterial effects of intracanal Nd:YAG laser irradiation. J Endod. 1994;20(8): 377-80.

84. Saunders WP, Whitters CJ, Strang R, Moseley H, Payne AP, McGadey J. The effect of an Nd-YAG pulsed laser on the cleaning of the root canal and the formation of a fused apical plug. Int Endod J. 1995; 28(4):213-20.

85. Fegan SE, Steiman HR. Comparative evaluation of the antibacterial effects of intracanal Nd:YAG laser irradiation: an in vitro study. J Endod. 1995; 21(8):4157.

86. Moshonov J, Orstavik D, Yamauchi S, Pettiette M, Trope M. Nd:YAG laser irradiation in root canal disinfection. Endod Dent Traumatol. 1995;11(5):220-4.

87. Harashima T, Takeda FH, Kimura Y, Matsumoto K. Effect of Nd:YAG laser irradiation for removal of intracanal debris and smear layer in extracted human teeth. J Clin Laser Med Surg. 1997;15(3):131-5.

88. Koba K, Kimura Y, Matsumoto K, Takeuchi T, Ikarugi T, Shimizu T. A histopathological study of the morphological changes at the apical seat and in the periapical region after irradiation with a pulsed Nd:YAG laser. Int Endod J. 1998;31(6):415-20.

89. 89. Santos C, Sousa-Neto MD, Alfredo E, Guerisoli DM, Pecora JD, Comelli Lia RF. Morphologic evaluation of the radicular dentine irradiated with Nd:YAG laser under different parameters and angles of incidence. Photomed Laser Surg. 2005;23(6): 590-5.
90. He H, Yu J, Song Y, Lu S, Liu H, Liu L. Thermal and morphological effects of the pulsed Nd:YAG laser on root canal surfaces. Photomed Laser Surg. 2009; 27(2):235-40.

91. Hasheminia SM, Birang R, Feizianfard M, Nasouri MA. Comparative study of the removal of smear layer by two endodontic irrigants and Nd:YAG laser: a scanning electron microscopic study. ISRN Dent. 2012; 6: 209- 51.

92. Takeda FH, Harashima T, Kimura Y, Matsumoto K.A comparative study of the removal of smear layer by three endodontic irrigants and two types of laser.Int Endod J, 1999;32:32-9.

93. Kimura Y, Yonaga K, Yokoyama K, Kinoshita J, Ogata $\mathrm{Y}$, Matsumoto K,et al. Root surface temperature increase during Er: YAG laser irradiation of root canals. J Endod, 2002;28:76-8.

94. Kivanç BH, Ulusoy OI, Görgül G. Effects of Er:YAG laser and Nd:YAG laser treatment on the root canal dentin of human teeth: a SEM study. Lasers Med Sci. 2008;23(3):247-52.

95. George R, Walsh LJ. Apical extrusion of root canal irrigants when using Er:YAG and Er, Cr:YSGG lasers with optical fi bers: an in vitro dye study. J Endod. 2008;34:706-8.

96. De Groot SD, Verhaagen B, Versluis M, Wu MK, Wesselink PR, van der Sluis LW. Laser-activated irrigation within root canals: cleaning efficacy and flow visualization. Int Endod J. 2009;42:1077-83.

97. De Moor RJ, Blanken J, Meire M, Verdaasdonk R. Laser induced explosive vapor and cavitation resulting in effective irrigation of the root canal. Part 2: evaluation of the efficacy. Lasers Surg Med. 2009;41:520-3.

98. Blanken J, De Moor RJG, Meire M, Verdaasdonk R. Laser induced explosive vapor and cavitation resulting in effective irrigation of the root canal. Part 1: a visualization study. Lasers Surg Med. 2009;41:514-9.

99. Peeters HH, Suardita K. Efficacy of smear layer removal at the root tip by using ethylenediaminetetraacetic acid and erbium, chromium: yttrium, scandium, gallium garnet laser. J Endod. 2011;37:1585-9. 
100. Guidotti R, Merigo E, Fornaini C, Rocca JP, Medioni E, Vescovi P. Er:YAG 2,940-nm laser fiber in endodontic treatment: a help in removing smear layer. Lasers Med Sci. 2014; 29(1): 69-75.

101.Bolhari B, Ehsani S, Etemadi A, Shafaq M, Nosrat A. Efficacy of Er, Cr:YSGG laser in removing smear layer and debris with two different output powers. Photomed Laser Surg. 2014;32:527-32.

102.Suman S, Verma P, Prakash-Tikku A, Bain R, KumarShakya V. A comparative evaluation of smear layer removal using apical negative pressure (EndoVac), sonic irrigation (EndoActivator) and Er:YAG laserAn in virto SEM study. J Clin Exp Dent. 2017; 9(8): 981987.

103. Mancini M, Cerroni L, Iorio L, Dall'Asta L \& Cianconi L. FESEM evaluation of smear layer removal using different irrigant activation methods (EndoActivator, EndoVac, PUI and LAI). An in-vitro study. Clinical Oral Investigations. 2018; 22:993-999.

104.DiVito E, Peters OA, Olivi G. Effectiveness of the erbium:YAG laser and new design radial and stripped tips in removing the smear layer after root canal instrumentation. Lasers Med Sci. 2012;27(2):273-80.

105.DiVito EE, Colonna MP, Olivi G. The photoacoustic effi cacy of an Er:YAG Laser with radial and stripped tips on root canal dentin walls: an SEM evaluation. J Laser Dent. 2011;19(1):156-61.

106. Olivi G, DiVito E. REVIEW Photoacoustic Endodontics using PIPS ${ }^{\mathrm{TM}}$ : experimental background and clinical protocol. Journal of the Laser and Health Academy, 2012;1 :22-25.

107.Lloyd A, Uhles JP, Clement DJ, Garcia-Godoy F. Elimination of intracanal tissue and debris through a novel laser-activated system assessed using highresolution micro-computed tomography: a pilot study. J Endod. 2014;40(4):584-7.

108.Hülsmann M, Rümmelin C, Schäfers F. Root canal cleanliness after preparation with different endodontic handpieces and hand instruments: a comparative SEM investigation. J Endod. 1997;23:301-6.

109.109. Ozbay Y, Erdemir A. Effect of Several Laser Systems on Removal of Smear Layer with a Variety of Irrigation Solutions. Microsc Res Tech. 2018 Oct;81(10):1214-1222
110.Korkut E, Torlak E, Gezgin O, Özer H, Şener Y. Antibacterial and Smear Layer Removal Efficacy of Er:YAG Laser Irradiation by Photon-Induced Photoacoustic Streaming in Primary Molar Root Canals: A Preliminary Study. Photomed Laser Surg. 2018; 36(9):480-486. 